Barbara Hryszko

ORCID: 0000-0002-1894-5454

Akademia Ignatianum w Krakowie

\title{
Utracone dziedzictwo „pierworodnej córy Kościoła” na przykładzie sfery sacrum dawnej Île de la Cité
}

Wyniosłym świątyniom powabnym szumem cześć oddaje [Sekwana], Uświęconą ziemię gładzi szumiąc żałośnie.

Krzywym dziobem w świątynie Dziewicy nie godzi,

Pruje wodę, zmniejsza siłę, spokojnie płynie.

Rozdzielona płynie przez środek miasta podwójnym nurtem

I z obydwu stron ogląda lśniące domy.

Bogowie, jak wspaniałe budowle, bogowie, jak wielkie pałace zwiedza! Niewiele one, moim zdaniem, gorsze od twoich Rzymie! ${ }^{1}$

Taki poetycki opis Île de la Cité - wyspy na Sekwanie stanowiącej serce stolicy Francji - wyszedł spod pióra Eustachego Knobelsdorfa (1519-1571), poety oraz kanonika warmińskiego i wrocławskiego². Miał on okazję podziwiać Paryż w czasie swych studiów we Francji. Za jego bytności wyspa w całej okazałości prezentowała swą średniowieczną zabudowę intensywnie nasyconą kościołami

\footnotetext{
E. Knobelsdorf, Opisanie Paryża, tłum. J. Mrukówna, wstęp i oprac. J. Starnawski, Łódź 1994, s. 15-16, wersy 191-198 (Literatura dla Wszystkich, 7).

2 Poeta dedykował swój łaciński utwór biskupowi chełmińskiemu Tydemanowi Gizjuszowi. Poemat pt. Lutetiae Parisiorum descriptio ukazał się po raz pierwszy drukiem w Paryżu w 1543 roku. Tłumaczenie na język polski opublikowano w 1994 roku.
} 
i kaplicami, nad którymi dominowała wyniosła katedra Naszej Pani (Nôtre-Dame). Wymowne jest przyrównanie przez Knobelsdorfa miasta do słynącego z pięknych świątyń Rzymu, będącego najważniejszym punktem odniesienia do oceny innych ośrodków miejskich, chociażby Krakowả3. Już samo porównanie do Wiecznego Miasta stanowiło rodzaj afektowanej gloryfikacji tak Krakowa, jak i Paryża. Co więcej, zestawienie to było uzasadnione nie tylko na płaszczyźnie przenośnej, ale i jak najbardziej materialnej: religijny charakter dawnej zabudowy paryskiej wyspy jest wyraźnie widoczny na starych mapach (il. 1, 2), stanowiących kartograficzne i ikonograficzne świadectwo ówczesnego wyglądu tej dzielnicy miasta. Warto odnotować, że obecny kształt zabudowy wyspy w niczym nie przypomina jej pierwotnego oblicza (il. 3).

Przywołanie obrazu średniowiecznej zabudowy tej najstarszej części miasta ma na celu odtworzenie jej dawnej wymowy ideowej. Zrekonstruowany obraz dawnej tkanki urbanistycznej kolebki stolicy Francji stanowi podstawę do namysłu nad charakterem jej utraconego religijnego i kulturowego dziedzictwa ${ }^{4}$ nie tylko w wymiarze materialnym, ale i duchowym. Budowle religijne stanowiące sferę sacrum zdecydowanie wyróżniały się spośród świeckiej zabudowy, nadając jej wyrazisty ton. We wschodniej części wyspy świątynie były związane z katedrą, w zachodniej - z siedzibą monarchy (il. 1, 2).

\section{Wschodnia część wyspy}

Na zespół katedralny, tj. grupę gmachów związanych z posługą biskupią, składały się dwa kościoły ustawione na osi: katedra św. Szczepana (Saint-Étienne) - jak się uważa przeznaczona dla katechumenów - i kościół Świętej Maryi (Sainte-Marie), zwany później Nôtre-Dame - dla ochrzczonych5 ${ }^{5}$ następnie

3 Zob. M. Fabiański, Przesławne miasto i drugi Rzym. Kraków i jego sztuka w oczach współczesnych w czasach największej świetności, w: Urbs celeberrima. Księga pamiątkowa na 750-lecie lokacji Krakowa, red. A. Grzybkowski, Z. Żygulski jun., T. Grzybkowska, Kraków 2008, s. 85-170.

$4 \mathrm{Na}$ temat procesu zniszczenia tego dziedzictwa: zob. B. Hryszko, Od sacrum do profanum. Desakralizacja Île de la Cité w Paryżu w XVIII i XIX wieku, w: Sacrum w mieście: wymiar kulturowy, religijny i społeczny, t. 2: Epoka nowożytna i czasy współczesne, red. D. Quirini-Popławska, Ł. Burkiewicz, Kraków 2016, s. 131-155; B. Hryszko, Rewolucja urbanistyczna na terenie Île de la Cité w Paryżu w XIX w. - przyczyny i skutki, „Studia Historyczne” 61 (2018) z. 3 (243), s. 33-44.

5 Zob. J. Hubert, Les origines de Notre-Dame de Paris, „Revue d'histoire de l'Église de France” $50(1964) \mathrm{n}^{\circ} 147$, s. 6; J. Hubert, Les „cathédrales doubles” et l'histoire de la liturgie, w: Atti del primo Convegno internazionale studi longobardi, Spoleto 1952, s. 167-176; J. Hubert, Les „cathédrales doubles” de la Gaule, w: Mélanges d'histoire et d’archéologie offerts en hommage à M. Louis Blondel, Genève 1963, s. 105-125. 
baptysterium św. Jana (Saint-Jean-le-Rond), siedziba biskupa oraz dzielnica kanoników zwana Clôitre Nôtre-Dame z kościołem św. Dionizego (Saint-Denis-du-Pas), kaplicą św. Aniana (Saint-Aignan) i szkołą katedralną (École cathédrale de Paris). Tego zbioru dopełnia szpital św. Krzysztofa (Hôpital Saint-Christophe) z kaplicą i klasztorem żeńskim oraz szpital Hôtel-Dieu z dwiema kaplicami: jedną przed fasadą katedry i drugą - św. Agnieszki (SaintAgnès) przy Petit-Pont.

Najważniejszym ogniwem w tym zespole była oczywiście katedra św. Szczepana. Świadczyły o tym zarówno jej monumentalne wymiary, jak i usytuowanie. Budowla została wzniesiona na miejscu świątyni pogańskiej być może już w IV wieku i przebudowana, prawdopodobnie w VII stuleciu, z powtórnym użyciem elementów starszych ${ }^{6}$. Jej usytuowanie i wygląd możemy rekonstruować na podstawie badań archeologicznych. W ich świetle wiemy, że fasada zachodnia była umieszczona 40 metrów na zachód od aktualnej fasady Nôtre-Dame, natomiast wschodnia część kościoła pokrywała się z pierwszym przęsłem obecnej gotyckiej katedry. O imponujących rozmiarach tego gmachu daje wyobrażenie fakt, że jego szerokość była niewiele mniejsza od późniejszej Nôtre-Dame (choć jednocześnie był od niej krótszy o około połowę). Katedra św. Szczepana miała pięć naw oddzielonych marmurowymi kolumnami i była ozdobiona mozaikami ${ }^{7}$. Jeszcze w 829 roku funkcjonowała jako główny kościół zespołu biskupiego ${ }^{8}$. Swój prymat na korzyść Nôtre-Dame ${ }^{9}$ straciła w drugiej połowie IX wieku.

Kościół Świętej Maryi ${ }^{10}$ znajdował się za katedrą św. Szczepana, w miejscu chóru obecnej katedry Nôtre-Dame. Prawdopodobnie pierwszy na tym obszarze kościół paleochrześcijański z IV wieku stanął na zrębach dawnej

${ }^{6}$ Zob. J. Hillairet, L'̂̂le de la Cité, Paris 1969, s. 99.

7 Zob. J. Hubert, Les origines..., dz. cyt., s. 9, 17-19.

8 Zob. Cartulaire général de Paris, ou Recueil de documents relatifs à l'histoire et à la topographie de Paris, formé et publié par R. de Lasteyrie, t. 1, 528-118o, Paris 1887, s. 49; J. Hillairet, L'̂̂le ..., dz. cyt., s. 99. Więcej na temat katedry św. Szczepana zob. M. Fleury, La cathédrale mérovingienne Saint-Étienne de Paris, „Dossiers d'Archéologie” novembre 1996 n² 218, s. 40-45; M. Fleury, La cathédrale mérovingienne Saint-Étienne de Paris, w: Landschaft und Geschichte. Festschrift für Franz Petri für seinem 65. Geburtstag, Hrgs. G. Droege, P. Schöller, R. Schützeichel, M. Zender, Bonn 1970, s. 211-221; M. Fleury, La crypte archéologique du parvis Notre-Dame à Paris, "Archéologia” octobre $1980 \mathrm{n}^{\circ}$ 147, s. 9-19.

9 Zob. J. Hillairet, L'Tlle..., dz. cyt., s. 99.

10 Jeszcze w 1101 roku kanonicy katedralni określali kościół dawnym wezwaniem Sainte-Marie. Zob. Cartulaire..., dz. cyt., s. 220, za: J. Hubert, Les origines..., dz. cyt., s. 17. 
pogańskiej świątyni z I wieku ${ }^{11}$. Odbudowany po pożarze w czasie inwazji Normanów w 857 roku $^{12}$ kościół zyskał przewagę nad sąsiednim kościołem św. Szczepana, stając się katedrą, następnie przebudowaną i powiększoną w stylu romańskim.

Pośrodku północnego boku katedry św. Szczepana, spełniając wymogi ówczesnej liturgii, znajdowało się baptysterium św. Jana, określane mianem Saint-Jean-le-Rond, datowane na pierwszą połowę $\mathrm{v}$ wieku ${ }^{13}$. Tymczasem według niepotwierdzonej tradycji kaplica chrzcielna pod wezwaniem św. Jana Chrzciciela (Saint-Jean-Baptiste) miała istnieć od v stulecia nie we wzmiankowanej rotundzie (le Rond), ale w miejscu lokalizacji późniejszego kościoła św. Germana (Saint-Germain-le-Vieux) ${ }^{14}$.

Po południowej stronie katedry mieściła się siedziba biskupa wspomniana w źródłach pisanych w $690 \mathrm{roku}^{15}$. Z kolei z północnej strony osi kościołów, do której należał jeszcze zbudowany przed xiI wieku kościół św. Dionizego zwany Saint-Denis-du-Pas ${ }^{16}$, usytuowany za prezbiterium Nôtre-Dame, znajdowała się dzielnica kanoników katedralnych odgrodzona murem od świata zewnętrznego ${ }^{17}$. Do mieszkań członków kapituły katedry można było przejść

${ }^{11}$ W czasie prac archeologicznych prowadzonych w latach 1710-1711 odnaleziono cokół monumentu dedykowanego Jupiterowi. Zob J. Hillairet, L'Île..., dz. cyt., s. 98; J. Hubert, Les origines..., dz. cyt., s. 6, 10.

${ }_{12}$ Zob. P. Périn, Paris mérovingien, 'sedes regia', „Klio - Beiträge zur Alten Geschichte” 71 (1989), s. 490; J. Hillairet, L'̂̂le ..., dz. cyt., s. 98-99; J. Hubert, Les origines..., dz. cyt., s. 5-26; B. Dumouchel, L’église Saint-Jean-le-Rond, „Bulletin de la Société de l'histoire de Paris et de l'Île-de-France” 118 (1991), s. 17-33.

${ }^{13}$ Jednak przydomek Le Rond odnajdujemy w dokumentach dopiero w XIII stuleciu. Zob. J. Pronteau, Étude sur le parvis Notre-Dame à Paris et les maisons des Enfants Trouvés au parvis, w: M. Fleury, J. Pronteau, Histoire de Paris, Paris 1974, s. 544-545 (École pratique des hautes études. $4^{\mathrm{e}}$ section, Sciences historiques et philologiques, 106); J. Hillairet, L'̂̂le ..., dz. cyt., s. 99, 126; J. Hubert, Les origines..., dz. cyt., s. 9, 15 .

${ }_{14}$ O baptysterium w tym miejscu pisze błędnie: [J.-B.-M.] Jaillot, Recherches critique historiques et topographiques sur la ville de Paris, avec une notice sur la vie et l'ouvre de l'auteur, par M. Fleury, t. 1: Quartier de la Cité, Paris 1977, s. 78-80; J. Hillairet, L'̂̂le..., dz. cyt., s. 126. Natomiast Hubert wykazuje, że baptysterium nigdy nie zmieniało swojego położenia. Zob. J. Hubert, Les origines..., dz. cyt., s. 11, 14; J. Pronteau, Étude..., dz. cyt., s. 544.

${ }_{15}$ Zob. Cartulaire..., dz. cyt., s. I7-I8; J. Hillairet, L'̂̂le..., dz. cyt., s. 121.

${ }^{16}$ Wg Hillaireta świątynia św. Dionizego istniała już w IX wieku. Wzmiankowana w 1148 roku jako odbudowana sumptem kanonika Simona de Poissy. Zob. J. Hillairet, L'Ile ..., dz. cyt., s. 127-128; B. Dumouchel, Léglise Saint-Denis-du-Pas, „Bulletin de la Société de l'histoire de Paris et de l'île-de-France" $119^{\mathrm{e}}$ à $122^{\mathrm{e}}$ années (1992-1993-1994), s. 95-115.

${ }_{17}$ Więcej na temat dzielnicy kanoników zob. R. Gane, Le Chapitre de Notre-Dame de Paris au XIve siècle. Étude sociale d'un groupe canonial, Saint-Etienne 1999, s. 55-68. 
przez wspomniany kościół św. Dionizego, co poniekąd odzwierciedla ostatni człon w jego nazwie, odnoszący się do niewielkiego przejścia przez rzekę

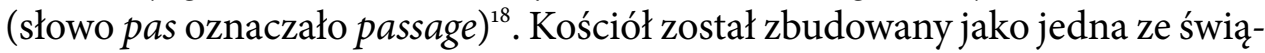
tyń stacyjnych procesji w czasie oktawy św. Dionizego - patrona Francji ${ }^{19}$.

W obrębie murów dzielnicy kanoników była usytuowana kaplica św. Aniana ufundowana przez jednego z członków kapituły katedralnej Étienne’a de Garlande’a przed rokiem 1121. Fundator był ówcześnie jednym z najbardziej wpływowych dostojników kościelnych. Piastował m.in. stanowiska dziekana Saint-Aignan d'Orléans, kanonika i archidiakona paryskiej Nôtre-Dame, kapelana królewskiego, kanclerza Francji i strażnika pieczęci królewskiej, a od 1121 roku także stolnika Francji ${ }^{20}$.

Klasztor kanoników dawał schronienie również prowadzonej przez nich szkole katedralnej, otwartej w połowie xI wieku, natomiast w 1128 roku przeniesionej poza mury dzielnicy w celu zapewnienia mieszkającym w niej duchownym spokojnej i pobożnej atmosfery ${ }^{21}$.

Już poza klasztorem, przed fasadą kościoła św. Szczepana, znajdował się szpital dla ubogich (Hôpital des Pauvres), zwany również szpitalem św. Krzysztofa ${ }^{22}$. Kanonicy katedralni służyli tu extra muros aż do 1006 roku $^{23}$, pełniąc posługę

${ }_{18}$ Zob. F. Heuzey, Curiosités de la cité de Paris. Histoire étymologique de ses rues nouvelles, anciennes ou supprimées, recherches archéologiques sur ses antiquités, monuments et maisons remarquables, Paris 1864, s. 147.

19 Do tej grupy kościołów należały kolejno: 1. Nôtre-Dame-des-Champs, miejsce, gdzie święty został pojmany z rozkazu prefekta rzymskiego Sisiniusa Fescenninusa (w tamtejszej krypcie św. Dionizy miał nauczać o kulcie Najświętszej Maryi Panny); 2. Saint-Etienne-des-Grès, gdzie wystawiano pastorał świętego; 3. Saint-Benoît-le-Bétourné, w którego krypcie św. Dionizy miał odprawiać mszę i głosić tajemnicę Trójcy Świętej; 4. Saint-Denis-du-Pas, gdzie miał doznawać pierwszych tortur na rozgrzanej kracie; 5 . Saint-Denis-de-la-Chartre, gdzie znajdowało się więzienie, w którym miał cudownie otrzymywać komunię; 6. Martyrium z Saint-Denis na Montmartre; 7. Saint-Denys de la Chapelle, w połowie drogi między miastem a bazyliką; 8. Grobowiec św. Dionizego zlokalizowany w bazylice Saint-Denis. Więcej na temat kościołów stacyjnych zob. S. McKnight Crosby, The Royal Abbey of SaintDenis: From Its Beginnings to the Death of Suger, 475-1151, ed. P. Z. Blum, New Heven-London 1987, s. 6, 457.

${ }^{20}$ Zob. L. Grant, F. Heber-Suffrin, D. Johnson, La chapelle Saint-Aignan à Paris, „Bulletin Monumental" t. 157 (1999) n 3, s. 283-285; J. Hillairet, L'T̂le..., dz. cyt., s. 128-129, 150.

${ }^{21}$ Zob. J. Hillairet, L'̂̂le..., dz. cyt., s. 46, 58.

${ }^{22}$ Pierwsza wzmianka o tej świątyni jest datowana na rok 69o. Zob. Cartulaire..., dz. cyt., s. 18; Pierwsza wzmianka o tej świątyni jest datowana na rok 690. J. Pronteau, Étude..., dz. cyt., s. 543. Przydzielenie kościoła kapitule Notre-Dame miało miejsce w 1097 roku. Zob. J. Hubert, Les origines..., dz. cyt., s. 17-19.

${ }_{23}$ Zob. J. Hillairet, L'̂̂le..., dz. cyt., s. 151. 
duszpasterską. Chorymi opiekowały się siostry z przyszpitalnego klasztoru ${ }^{24}$. Według tradycji, poświadczonej w XVII wieku, szpital został ufundowany w viI wieku przez biskupa Paryża, św. Landeryka ${ }^{25}$. Natomiast pierwsza historyczna wzmianka o szpitalu pochodzi z roku 829: wówczas to mieszkania biednych i chorych zostały przyłączone do kaplicy św. Krzysztofa (Saint-Christophe). W IX wieku rozbudowano szpital jako przytułek dla ubogich i chorych oraz szpital dla podróżnych i obcokrajowców (Hôtel-Dieu-Saint-Christophe ${ }^{26}$.

Południowo-wschodnia część wyspy, skupiająca gmachy związane z posługą biskupią, stała się w drugiej połowie xıI wieku wielkim placem budowy. W obrębie zespołu katedralnego nastąpiły wówczas fundamentalne zmiany strukturalne polegające na zburzeniu w 1163 roku bazyliki św. Szczepana ${ }^{27}$, której stan określono jak katastrofalny, oraz szpitala ubogich, a następnie wzniesieniu nowych gmachów. Na miejscu katedry romańskiej powstała stojąca do dziś monumentalna katedra Nôtre-Dame. W trakcie prac budowlanych zapewne wykorzystano materiał z kościoła św. Szczepana ze względów praktycznych, ale mogło być to również przejawem szacunku dla materiału pochodzącego ze zburzonej świątyni. Prace rozpoczęto w 1160 roku $\mathrm{z}$ inicjatywy biskupa Maurice’a de Sully ${ }^{28}$. O wiele większy gmach w stylu gotyckim określanym w źródłach jako opus francigenum ${ }^{29}$, miał pomieścić ludność Paryża, której liczba gwałtownie wzrosła w pierwszej połowie XII wieku. Biskup de Sully rozpoczął również budowę pałacu biskupiego i szpitala zwanego odtąd Hôtel-Dieu ${ }^{30}$. Szpital posiadał dwie kaplice, jedną przed prowadzącym do katedry portalem św. Anny oraz drugą, pod wezwaniem

${ }^{24}$ Zakon był określany jako Filles de Saint-Christophe, później Dames Augustines: Ch. Coury, L'Hôtel-Dieu de Paris, treize siècles de soins, d'enseignement et de recherche, Paris 1969, s. 64.

${ }_{25}$ Zob. J. Hillairet, L'Île..., dz. cyt., s. 151; Ch. Coury, L'Hôtel-Dieu..., dz. cyt., s. 7 .

${ }^{26}$ Takie podwójne określenie pojawia się w listach patentowych z xıI wieku. Zob. J. Hillairet, L'Tlle..., dz. cyt., s. 151-152. Więcej na temat budowli znajdujących się przed obecną fasadą katedry Nôtre-Dame zob. M. Fleury, La crypte archéologique..., dz. cyt., s. 9-19.

${ }^{27}$ Kościół popadł w ruinę na początku xıI wieku. Zob. J. Hillairet, L'̂̂le..., dz. cyt., s. 99-100; J. Pronteau, Étude..., dz. cyt., s. 538.

${ }^{28}$ Zob. J. Hillairet, L'T̂le..., dz. cyt., s. 99-100; J. Henriet, A l'aube de l'architecture gothique, Besançon 2005, s. 43-56; A. Erlande-Brandenburg, Le grand dessein de Maurice de Sully (1160), $\mathrm{w}$ : Notre-Dame de Paris. Un manifeste chrétien, 1160-1230. Colloque organisé à l'Institut de France le vendredi 12 décembre 2003, actes édités par M. Lemoine, Turnhout 2004, s. 71-92 (Rencontres Médiévales Européennes, 4).

${ }^{29}$ Na temat procesu wznoszenia gotyckiego gmachu zob. J. Henriet, A l'aube de l'architecture..., dz. cyt., s. 43-56, 283-30o.

3o Zob. M. Foncin, La Cité, „Annales de Géographie” 40 (1931) n 227, s. 490. 
św. Agnieszki (Saint-Agnès, XıII.) ${ }^{31}$, usytuowaną nad Sekwaną obok Petit-Pont. Powodem wielkiej akcji budowlanej w drugiej połowie XII wieku był nie tylko cel praktyczny, polegający na poprawieniu warunków sprawowania liturgii dla coraz liczniejszej społeczności miasta, ale również względy ideowo-religijne i artystyczne, tj. wzniesienie wspanialszej budowli w nowym stylu. Zmiany stylistyczne objęły również baptysterium św. Jana: w XıII wieku przebudowano je $\mathrm{z}$ formy kolistej na budowlę gotycką na planie prostokąta ${ }^{32}$.

\section{Zachodnia część wyspy}

Na zachodnim krańcu wyspy dominował pałac królewski - centrum władzy świeckiej, z którym były związane następujące świątynie: klasztor św. Marcjala (Saint-Martial), kościół św. Eligiusza (Saint-Eloi), kościół św. Piotra (Saint-Pierre-aux-Arcis), kościół Świętego Krzyża (Sainte-Croix), kościół św. Bartłomieja (Saint-Barthélemy), kaplica św. Mikołaja (Saint-Nicolas, później zastąpiona przez Sainte-Chapelle) i kaplica św. Michała (Saint-Michel-du-Palais).

Klasztor św. Marcjala został założony przez króla Franków Dagoberta I w latach trzydziestych viI wieku z inicjatywy św. Eligiusza, kanclerza królewskie$\mathrm{go}^{33}$. W obszernym gmachu mieszkało 300 zakonnic kierowanych przez mającą syryjskie korzenie ksienię Aurorę, późniejszą świętą ${ }^{34}$. Kilka lat po śmierci św. Aurory, w latach siedemdziesiątych viI wieku, kościół św. Marcjala przyjął wezwanie św. Eligiusza i św. Aurory (Saint-Éloi-et-Sainte-Aure) ${ }^{35}$. Jednak w 1107 roku, po stwierdzeniu moralnego zepsucia tutejszych zakonnic, biskup Paryża Gwalon rozesłał je między różne klasztory, a opuszczone budynki przekazał benedyktynom. W czasie tej reformy kościół klasztorny został przedzielony przez publiczną uliczkę, w rezultacie dawne prezbiterium stało się kościołem parafialnym pod wezwaniem św. Marcjala, a nawa - kościołem zakonnym pod wezwaniem św. Eligiusza ${ }^{36}$. Od klasztoru św. Eligiusza był zależny sąsiedni

${ }^{31}$ Zob. M. Fosseyeux, L'Hôtel-Dieu de Paris au Xvile et XviIIe siècle, Paris 1912, s. 237-241, $243-246$.

${ }^{32}$ Zob. J. Pronteau, Étude..., dz. cyt., s. 545.

33 Zob. P. Périn, Paris mérovingien..., dz. cyt., s. 491.

34 Zob. J. Lafaurie, Eligius monetarius, „Revue numismatique” $6^{\text {e }}$ serie, t. 19 (1977), s. 115-116, 132.

${ }_{35}$ Zob. F. Dolbeau, Vie et Miracles de sainte Aure, abbesse, jadis vénérée à Paris, „Bollandiana. Revue critique d'hagiographie" 125 (2007) nº ${ }^{1}$, s. 17-91.

${ }^{36}$ Zob. J. Hillairet, L'̂̂le..., dz. cyt., s. 25, 136-137; X. Dectot, Sculptures des XIe-XIIe siècles, roman et premier art gothique. Catalogue Musée national du Moyen Âge Thermes de Cluny, Paris 2005, s. 95 . 
kościół św. Piotra, który został założony w 926 roku przez możnowładcę Theudona Le Riche'a, wicehrabiego Paryża ${ }^{37}$. Na terenie klasztoru św. Eligiusza zbudowano także, jeszcze przed xı stuleciem, kościół Świętego Krzyża. Przeznaczony do przechowywania relikwii krzyża, funkcjonował jako kościół parafialny od 1107 roku. W 1136 roku został przebudowany i powiększony ${ }^{38}$.

Kolejny obiekt sakralny w zachodniej części wyspy, czyli kościół św. Bartłomieja usytuowany naprzeciwko wielkiej sali pałacu, powstał prawdopodobnie ok. 890 roku w wyniku fundacji króla Odona jako kolegialny dla zgromadzenia kanoników. Niedługo potem, w połowie x wieku, król Hugo Kapet wybrał ten kościół jako miejsce przechowywania relikwii sprowadzonych z Bretanii najechanej przez Normanów ${ }^{39}$, w tym m.in. relikwii świętego, na którego cześć dodano wezwanie Saint-Magloire do wezwania Saint-Barthélemy ${ }^{40}$. W 1183 roku powrócono do głównego wezwania, czyniąc kościół parafialnym dla całego dworu ${ }^{41}$.

W obrębie samego pałacu królewskiego znajdowała się kaplica św. Mikołaja wzniesiona na początku XI wieku podczas przebudowy siedziby monarszej pod koniec panowania Roberta II Pobożnego (972-1031) ${ }^{42}$. W latach 1241-1248

37 Przydomek Arcis pochodzi od łacińskiego arcisterium oznaczającego klasztor i miejsca sąsiednie, które są od niego zależne. Zob. F. Heuzey, Curiosités..., dz. cyt., s. 74; J. Hillairet, L'̂̂le..., dz. cyt., s. 137; B. Dumouchel, Léglise Saint-Pierre-aux-Bœufs, „Bulletin de la Société historique de Paris et de l'île-de-France” 122/124 (1995-1997 [1999]), s. 15-20. Wzmianka o fundacji kościoła zob. Dictionnaire des dates, des faits, des lieux et des hommes historiques; ou, Les tables de l'histoire, répertoire alphabétique de chronologie universelle, sous la direction de A.-L. d'Harmonville, t. 2, Paris 1843, s. 591.

${ }_{38}$ Zob. F. Heuzey, Curiosités..., dz. cyt., s. 76-77; B. Bove, Espace, piété et parenté à Paris aux XIII-XIVe siècles d’après les fondations d’anniversaires des familles échevinales, $\mathrm{w}$ : Religion et société urbaine au Moyen Age. Mélanges offerts à Jean-Louis Biget, Paris 2000, s. 259 (Temps \& Espaces).

39 Więcej na ten temat zob. J.-L. Deuffic, L'exode des corps saints hors de Bretagne (vIIe-XIIe s.): des reliques au culte liturgique, w: Reliques et sainteté dans l’espace médiéval, éd. J.-L. Deuffic, „PECIA. Ressources en médiévistique" 8-11 (2005), s. 355-423, https://doi.org/10.1484/J.PECIA.5.101568 (27.09.2018); J. Pysiak, Król i Korona Cierniowa. Kult relikwii we Francji Kapetyngów, Warszawa 2012, s. 159-160.

${ }^{0}$ Zob. J. Hillairet, L'T̂le..., dz. cyt., s. 139; R. Merlet, Les origines du monastère de Saint-Magloire de Paris, „Bibliothèque de l'École des chartes” 56 (1895), s. 238.

${ }^{41}$ Zob. J. Hillairet, Lîle..., dz. cyt., s. 140; http://data.bnf.fr/13508340/paroisse_saint-barthelemy_ paris/ (27.09.2018).

${ }^{42}$ Zob. J. Hillairet, L'Tlle..., dz. cyt., s. 167-168; O.V. Lefranc, Racines orientales du système monarchique des Capétiens. Les reliques de la Passion, „Revue Française d'Histoire des Idées Politiques" 2002/1 ( $\mathrm{n}^{\circ}$ 15), s. 3-15; H. Delhumeau, Le palais de la Cité, du Palais des rois de France au Palais de Justice, Paris 2011, s. 28; B. Bove, Les palais royaux à Paris au Moyen Age (XIe-Xve 
na jej miejscu została ufundowana przez św. Ludwika IX nowa gotycka kaplica pałacowa - słynna Święta Kaplica (Sainte-Chapelle) przeznaczona do przechowywania relikwii Męki Pańskiej (m.in. korony cierniowej i fragmentu krzyża) ${ }^{43}$. Po południowej stronie aktualnego dziedzińca Sainte-Chapelle zbudowano ok. 1159 roku za panowania Ludwika viı kaplicę św. Michała ${ }^{44}$. Syn Ludwika, przyszły król Filip August, został tam ochrzczony w 1165 roku przez biskupa Paryża Maurice’a de Sully. Wspomniany monarcha w 1210 roku ufundował przy kaplicy Bractwo Pielgrzymów Mont-Saint-Michel (Confrérie des Pèlerins du Mont-Saint-Michel).

\section{Środkowa część wyspy}

W centrum Île de la Cité, pomiędzy centrami władzy świeckiej oraz duchowej, znajdowało się osiem budowli sakralnych: kościół św. Dionizego (Saint-Denis-de-la-Chartre), kaplica św. Symforiusza (Saint-Symphorien-de-la-Chartre) później św. Łukasza (Saint-Luc), kaplica św. Mikołaja (Saint-Nicolas) - później św. Landeryka (Saint-Landry), kościół św. Genowefy (Sainte-Geneviève-la-Petite lub Sainte-Geneviève-des Ardents), kościół św. Germana (Saint-Germain-le-Vieux), kościół św. Mariny (Sainte-Marine), kościół św. Piotra (Saint-Pierre-aux-Bœufs) oraz synagoga - przekształcona w kościół św. Marii Magdaleny (Sainte-Marie-Madeleine).

Kościół św. Dionizego, zwany Saint-Denis-de-la-Chartre - druga na wyspie świątynia stacyjna procesji ku czci patrona królestwa ${ }^{45}$ - wiąże się z legendą

siècles), w: Palais et Pouvoir, de Constantinople à Versailles, dir. M.-F. Auzepy, J. Cornette, Saint-Denis 2003, s. 47.

${ }^{43}$ Zob. S.-J. Morand, Histoire de la Ste-Chapelle royale du Palais, enrichie de planches, Paris 1790, s. 26-30, 68, 127; O. V. Lefranc, Racines..., dz. cyt., s. 3-15. Na temat konstrukcji i stanu zachowania kaplicy zob. J.-M. Leniaud, F. Perrot, La Sainte-Chapelle, Paris 1991; M. Cohen, The Sainte-Chapelle and the Construction of Sacral Monarchy. Royal Architecture in Thirteenth-Century Paris, Cambridge 2014, passim. Na temat kultu relikwii Męki Pańskiej za panowania Ludwika IX zob. J. Pysiak, Król..., dz. cyt., s. 251-383. O Sainte-Chapelle w czasach św. Ludwika zob. L. Archon, Histoire ecclesiastique de la Chapelle des rois de France, t. 2, Paris 1711, s. 125-168.

${ }_{44}$ Zob. S.-J. Morand, Histoire..., dz. cyt., s. 133; L. Archon, Histoire..., dz. cyt., t. 2, s. 70; M. Nortier, La chapelle Saint-Michel du Palais à Paris, siège de la confrérie de pèlerins du Mont-Saint-Michel, „Les Amis du Mont-Saint-Michel” 2000 n 105, s. 32-45; M. Cohen, The Sainte-Chapelle..., dz. cyt., s. 129-131; E. Dehoux, Prétentions et revendications du roi capétien. Saint Michel, le prince et la loi (XıIe-XIIIe siècles), w: Le roi fontaine de justice. Pouvoir justicier et pouvoir royal au Moyen Âge et à la Renaissance, sous la dir. de B. Meniel et B. Ribemont, Paris 2012, s. 105-106.

45 Patrz przyp. 18. 
o świętym, który miał być w tym miejscu więziony w znajdującym się tam lochu (późniejszej krypcie) i mimo zamknięcia cudownie otrzymać komunię $\mathrm{z}$ rąk samego Jezusa. Wyrazem pamięci o tym wydarzeniu jest przydomek kościoła (słowo la chartre oznaczało niegdyś więzienie bądź karcer). Budowla została źródłowo potwierdzona dopiero w XI wieku ${ }^{46}$.

W sąsiedztwie kościoła św. Dionizego Mateusz iI, baron de Montmorency (zm. 1230), wielki konetabl w służbie królewskiej, ufundował w 1206 roku kaplicę św. Symforiusza. Był to jego akt przebłagalny za niewypełnienie ślubów odbycia pielgrzymki do Palestyny ${ }^{47}$. Kościół stał się kolegiackim, później parafialnym ${ }^{48}$. Niemal pięć wieków później, po zamknięciu świątyni w 1698 roku i sprzedaniu jej w 1704 roku Akademii św. Łukasza w Paryżu (Académie de Saint-Luc de Paris), zrzeszającej malarzy, rzeźbiarzy, iluminatorów i grafików, kaplicę poświęcono patronowi artystów św. Łukaszowi ${ }^{49}$.

Zmiana patrona miała miejsce także w przypadku kaplicy św. Mikołaja, która została przemianowana na kościół św. Landeryka w IX wieku, po przeniesieniu tutaj z kościoła św. Germana z Auxerre (Saint-Germain l’Auxerrois) relikwii tego świętego biskupa Paryża ${ }^{50}$, żyjącego w VII wieku i znanego z wielkiej dobroczynności, której najpełniejszy wyraz dał, zakładając dla ubogich szpital św. Krzysztofa ${ }^{51}$.

Landeryk to nie jedyny święty związany za życia z wyspą na Sekwanie. Kolejną postacią jest św. Genowefa, która - według legendy - po osieroceniu przez rodziców przybyła z Nanterre do Paryża, aby zamieszkać na Cité u swojej matki chrzestnej. Na miejscu jej dawnego domu powstał w IX wieku kościół. Legendarny przekaz znalazł odbicie w przydomku świątyni - Sainte-Geneviève-la-Petite ${ }^{52}$.

${ }^{46}$ Zob. B. Dumouchel, Le prieuré de Saint-Denis de La Chartre, „Paris et Île-de-France. Mémoires publiés par la Fédération des Sociétés historiques et archéologiques de Paris et de l'Île-de-France" 49 (1998), s. 7-26.

47 Zob. B. Dumouchel, L’église Saint-Germain-le-Vieux, „Bulletin de la Société de l'histoire de Paris et de l'̂̂le-de-France" $117^{\mathrm{e}}$ année (1990 [1992]), s. 61-63, 65.

${ }^{48}$ Hillairet jako czas powstania podaje viI wiek, bez wskazania źródła tej informacji. Zob. J. Hillairet, L'Île..., dz. cyt., s. 150.

49 Zob. B. Dumouchel, Léglise Saint-Symphorien-en-la-Cité (1206-1868), „Bulletin de la Société de l'histoire de Paris et de l'Île-de-France" $113^{\mathrm{e}}$ et $114^{\mathrm{e}}$ années (1986-1987 [1988]), s. 71-76.

${ }^{50}$ Zob. J. Hillairet, Lîlle..., dz. cyt., s. 130-133.

${ }^{51}$ Patrz przyp. 23.

52 Początki kościoła św. Genowefy pozostają nieznane. Zob. J. Pronteau, Étude..., dz. cyt., s. 541-542. Historycy wskazują, że budowa świątyni mogła mieć miejsce w okresie po zakończeniu 
Natomiast drugie znane określenie - Sainte-Geneviève-des Ardents - wiąże się z pierwszymi historycznymi wzmiankami z 1129 roku na temat nękającej Paryż choroby zwanej mal des ardente. Dzięki modlitwie przed relikwiarzem patronki Paryża, który został przeniesiony do katedry, odnotowano liczne cuda ${ }^{53}$.

Ze św. Genowefą związany jest jeszcze jeden kościół na wyspie - Saint-Germain-le-Vieux, gdzie według tradycji miała ona gromadzić kobiety, aby się wspólnie modlić podczas najazdu Atylii na Paryż w 451 roku $^{54}$. W związku $\mathrm{z}$ tymi wydarzeniami uważa się, że kościół św. Germana zbudowano w v wie$\mathrm{ku}^{55}$, jednak brak źródeł potwierdzających tę tradycję. W kościele zarządzanym przez mnichów z Saint-Germain-des-Prés przechowywano relikwie patrona kościoła $^{56}$.

Innym sakralnym przybytkiem związanym z lokalną świętą był kościół św. Mariny, którego początki sięgają XI wiekư ${ }^{57}$. Dawne opisy Paryża zawierają osobliwą historię o Marinie, która wstąpiła do męskiego klasztoru jako brat Marin $^{58}$. Jego obowiązkiem było zaopatrzenie zakonu w żywność. Niesprawiedliwie oskarżony przez córkę szlachcica o nazwisku de Pandoche, jakoby za jego przyczyną zaszła w ciążę, zakonnik został wygnany z klasztoru. Oddano mu również urodzone przez kobietę dziecko, którym opiekował się, jakby było jego własnym. Kanonicy poruszeni postawą brata pozwoli powrócić mu do klasztoru. Dopiero po śmierci odkryto prawdę o jego żeńskiej tożsamości. Marinę po przypisywanych jej cudach ogłoszono świętą, którą czczono w kościele znajdującym się w sąsiedztwie dzielnicy kanoników ${ }^{59}$.

oblężenia Paryża w 886 r. Zob. J. Pronteau, Étude..., dz. cyt., s. 542; E. Bourassin, Sainte Geneviève, Monaco 1997, s. 36.

${ }_{53}$ Zob. Cartulaire..., dz. cyt., s. 234. Więcej na temat wezwania Sainte-Geneviève-la-Petite lub des Ardents zob. F. Heuzey, Curiosités..., dz. cyt., s. 87.

${ }^{54}$ Zob. B. Dumouchel, L’église Saint-Germain-le-Vieux..., dz. cyt., s. 2o; K. Escher, I. Lebedynsky, Le dossier Attila, Paris 2007, s. 144.

${ }_{55}$ Zob. B. Dumouchel, L’église Saint-Germain-le-Vieux..., dz. cyt., s. 20-23. Z kolei Hillairet podaje rok 580. Zob. J. Hillairet, Lîle..., dz. cyt., s. 150.

${ }_{56}$ Zob. F. Heuzey, Curiosités..., dz. cyt., s. 70-71; B. Dumouchel, L’église Saint-Germain-le-Vieux..., dz. cyt., s. 22, 24.

57 Hillairet wskazuje, że kościół został ufundowany w 1045 roku, natomiast w 1205 roku utworzono przy nim parafię. Zob. J. Hillairet, L'̂̂le..., dz. cyt., s. 15o. Zob. również: B. Dumouchel, L’église Sainte-Marine, „Bulletin de la Société de l'histoire de Paris et de l'Île-de-France” $125^{\mathrm{e}}$ à $128^{\mathrm{e}}$ années (1998-1999-2000-2001 [2002]), s. 31-47.

${ }_{58}$ Zob. J. de Gaulle, Nouvelle histoire de Paris et de ses environs, Paris 1839, s. 386-387; F. Heuzey, Curiosités..., dz. cyt., s. 118-119.

59 Zob. J. de Gaulle, Nouvelle histoire..., dz. cyt., s. 386-387. 
W pobliżu wznosił się również kościół św. Piotra (Saint-Pierre-aux-Bœufs). Choć wzmiankowany dopiero w 1136 roku, prawdopodobnie istniał już w x wieku. Nazwa świątyni może wskazywać, że była to parafia rzeźników na Cité. Ewentualnie przydomek jest wspomnieniem jakiegoś cudu bądź wydarzenia związanego $\mathrm{z}$ rodem Le Bœuf ${ }^{60}$.

Warto jeszcze wspomnieć, że w centrum Cité, przy rue de Juiverie - będącej główną arterią dzielnicy żydowskiej - znajdowała się górująca nad nią synagoga ${ }^{6}$. Pod koniec XII wieku, w wyniku wygnania Żydów z Francji na mocy decyzji wydanej w 1182 r. przez króla Filipa II Augusta, mieszcząca się w centrum wyspy bożnica została przemianowana na kościół św. Marii Magdaleny. Stał się on wkrótce siedzibą najznamienitszych bractw Paryża, zrzeszających zarówno arystokrację, jak i mieszczan ${ }^{62}$.

Wieki XII i XIII to apogeum rozwoju sieci kościołów na Île de la Cité. Wyburzenie w tym okresie dawnej katedry św. Szczepana, szpitala i baptysterium oraz kaplicy pałacowej św. Mikołaja powodowane było chęcią zastąpienia ich nowymi, wspanialszymi gmachami w modnym wówczas stylu gotyckim. Z kolei przekształcenie synagogi w kościół motywowane było względami religijno-politycznymi. Pod koniec średniowiecza tkanka urbanistyczna paryskiej wyspy była zdominowana przez 22 budowle sakralne nadające ton tej części miasta.

\section{Przemiany na wyspie}

Z biegiem czasu budowle sakralne na wyspie ulegały przemianom i niszczały, w następstwie czego sukcesywnie podejmowano różnorakie naprawy, a nawet rozbudowy poszczególnych gmachów lub - przeciwnie - decyzję o ich wyburzeniu. Tempo tych powolnych zmian uległo przyśpieszeniu w XVIII wieku, kiedy wyburzono kościoły św. Marcjala (1722), św. Genowefy i św. Krzysztofa

${ }^{60}$ Zob. B. Dumouchel, Leéglise Saint-Pierre-aux-Bœufs..., dz. cyt., s. 15-17.

${ }^{61}$ Zob. J. Hillairet, L'Tlle..., dz. cyt., s. 34-36; B. Dumouchel, Léglise Sainte-Marie-Madeleine ou La Madeleine-en-la-Cité (1182-1794), „Bulletin de la Société de l'histoire de Paris et de l'̂̂le-de-France" $115^{\mathrm{e}}$ année (1988, [1989]), s. 21-45.

${ }^{62}$ Zob. J. Hillairet, L'Ile ..., dz. cyt., s. 34-35; B. Dumouchel, Léglise Sainte-Marie-Madeleine..., dz. cyt., s. 21-45. 
(1747), baptysterium św. Jana (1748) oraz kaplicę św. Michała (1781-1782) ${ }^{63}$. Najmocniejszym niszczycielskim akordem wieku oświecenia była rewolucja francuska i jej następstwa, tj. sprzedaż budowli związanych z kultem religijnym i ich desakralizacja. Choć w czasach rewolucji francuskiej zburzono na Cité tylko jeden kościół (św. Marii Magdaleny, 1794 ${ }^{64}$ ), jej konsekwencje okazały się dla sfery sacrum najgroźniejsze, ponieważ były zakorzenione w ideologicznych pobudkach. Na skutek nowej, rewolucyjnej ideologii usuwano przejawy religii chrześcijańskiej z przestrzeni miejskiej. W pierwszej połowie XIX wieku zburzono następujące świątynie: św. Germana (Saint-Germain-le-Vieux, 1802) ${ }^{65}$, św. Agnieszki (Saint-Agnès, 1802-1803) ${ }^{66}$, św. Dionizego (Saint-Denis-de-la-Chartre, $1808^{67}$; Saint-Denis-du-Pas, 1813-1814) ${ }^{68}$, św. Landeryka (Saint-Landry, 1829$)^{69}$ oraz św. Piotra (Saint-Pierre-aux-Bœufs, 1837$)^{70}$.

Jednak najbardziej drastyczne zmiany miały miejsce $\mathrm{w}$ drugiej połowie XIX wieku, kiedy to średniowieczna tkanka miejska wyspy uległa unicestwieniu $^{71}$. Należy podkreślić, że wówczas istniały już tylko dwa, zresztą zdesakralizowane wcześniej kościoły: św. Mariny i św. Bartłomieja (ten ostatni funkcjonował jako sala balowa Le Prado). Głównym celem przebudowy zarządzonej przez Napoleona II i realizowanej pod kontrolą barona Georges’a Eugène’a Haussmanna nie było ideowe usuwanie świątyń, lecz likwidacja niehigienicznej i nieużytecznej średniowiecznej zabudowy Cité, czyli tła dla nieistniejącej już sfery sacrum ${ }^{72}$. Na uzyskanej w ten sposób pustej przestrzeni zbudowano gmachy użyteczności publicznej: Trybunał Handlu, koszary (późniejsza prefektura policji), nowy szpital - Hôtel-Dieu, oraz rozbudowano Pałac Sprawiedliwości (il. 3). Pozostawiono jedynie katedrę Nôtre-Dame (choć

${ }^{63}$ Więcej na ten temat zob. B. Hryszko, Od sacrum..., dz. cyt., s. 131-155.

${ }^{64}$ Zob. B. Dumouchel, L'église Sainte-Marie-Madeleine..., dz. cyt., s. 21-45.

${ }_{5}$ Zob. B. Dumouchel, Léglise Saint-Germain-le-Vieux..., dz. cyt., s. 42.

${ }^{66}$ Zob. M. Fosseyeux, L'Hôtel-Dieu..., dz. cyt., s. 246.

${ }_{67}$ Zob. J. Hillairet, L'̂̂le..., dz. cyt., s. 150.

${ }^{68}$ Zob. J. Hillairet, L'̂̂le..., dz. cyt., s. 128; B. Dumouchel, Léglise Saint-Denis-du-Pas..., dz. cyt., s. $110-115$.

69 Zob. J. Hillairet, Lîle..., dz. cyt., s. 150.

70 Zob. B. Dumouchel, Léglise Saint-Pierre-aux-Bœufs..., dz. cyt., s. 31-35; E. Renaudin, Paris-exposition ou guide à Paris en 1867. Histoire, monuments, musées, théâtres, curiosités vie pratique, Paris 1867 , s. 20.

${ }^{71}$ Więcej na ten temat zob. B. Hryszko, Rewolucja..., dz. cyt., s. 33-44.

${ }^{72}$ Zob. P.-A. Touttain, Haussmann: artisan du Second Empire, créateur du Paris moderne, Paris 1971, s. 62. 
zburzono stojące w pobliżu jej frontu zabudowania, tworząc szeroki dziedziniec), przebudowano pałac królewski z Sainte-Chapelle oraz część dawnej zdesakralizowanej dzielnicy kanoników (il. 3). Średniowieczna tkanka miasta została bezpowrotnie utracona.

\section{Znaczenie dawnej sfery sacrum}

Na podstawie historii wyspy, jej dawnej tradycji i ikonografii, starych map oraz wezwań kościołów można pokusić się o próbę odtworzenia wymowy ideowej zawartej w strefie sacrum, jaka przez wieki średnie porządkowała przestrzeń na Île de la Cité. Należy zaznaczyć, że tamtejsza sieć kościołów - wielowarstwowa i niejednorodna, kształtowana powoli w ciągu kolejnych stuleci - odzwierciedlała dzieje tego skrawka ziemi, stanowiąc świadectwo dawnej pobożności oraz wartości ważnych dla fundatorów, duszpasterzy i społeczności wiernych. Strefa sacrum tego wyjątkowego miejsca stanowiła istotę dawnej francuskiej religijności, w której była zakorzeniona cała tradycyjna kultura tego narodu.

Sylwetki kościołów wyróżniały się rozmiarami, górując wśród skromniejszej świeckiej zabudowy. Na tym tle swoimi wertykalnymi proporcjami, strzelistością i monumentalnymi wymiarami, ale i bogactwem artystycznym szczególnie dominowały dwie budowle: katedra Nôtre-Dame i kaplica zwana Sainte-Chapelle, wpisana w równie okazały pałac monarszy. Te dwa punkty symbolicznie i materialnie uosabiały współistnienie na wyspie dwóch ośrodków władzy duchowej i świeckiej.

Gmachy wchodzące w skład zespołu katedralnego odgrywały najważniejszą rolę w administracji kościelnej związanej z biskupstwem stolicy Francji i realizowaną tam misją duszpasterską. Towarzyszyły im budowle pełniące funkcję dobroczynną i opiekuńczą (szpital św. Krzysztofa z kaplicą i klasztorem żeńskim oraz szpital Hôtel-Dieu z dwiema kaplicami), a także edukacyjną (szkoła katedralna - École cathédrale de Paris). Instytucje te realizowały ważne posłannictwa kościoła - misję nauczycielską i działalność charytatywną, polegającą na opiece nad ubogimi, chorymi i przybyszami, np. podróżnymi i pielgrzymami. Funkcje wspomnianych budowli poświadczają, na jakich kwestiach ogniskowała się uwaga ówczesnej wspólnoty Kościoła.

Natomiast wokół centrum władzy świeckiej - pałacu królewskiego (wyposażonego w dwie kaplice: św. Mikołaja, zastąpioną przez Sainte-Chapelle, oraz św. Michała) - były skupione świątynie ufundowane przez władców (kościoły: św. Marcjala, św. Bartłomieja) lub ich otoczenie (kościół św. Piotra). Miały one nie tylko znaczenie religijne, lecz także polityczne i propagandowe. Świadczyły 
o pobożności i hojności francuskich monarchów noszących honorowy tytuł królów arcychrześcijańskich (rois très chrétiens).

Warto zwrócić uwagę, że wyjątkowym wzmocnieniem ideowego przekazu o nadprzyrodzonym pochodzeniu władzy króla jako pomazańca Pańskiego i christus Domini były święte relikwie przechowywane w kościołach: św. Bartłomieja, Świętego Krzyża, a zwłaszcza w Sainte-Chapelle ${ }^{73}$. Nie tylko podnosiły one status danego kościoła, ale i uczestniczyły w procesie uświęcania władzy królewskiej. Już od xI wieku kult relikwii jako przejaw żarliwego nabożeństwa kolejnych królów Francji był czynnikiem kształtującej się wówczas teologii politycznej monarchii Kapetyngów ${ }^{74}$. Królowie szukali u świętych patronów wsparcia, ale i bywało, że uważali się wręcz za panów ich relikwii, a nawet za szczególnych przyjaciół świętych ${ }^{75}$. Dla kolejnych monarchów największe znaczenie miały relikwie Męki Pańskiej, wcześniej przechowywane w Akwizgranie i bazylice św. Dionizego (Saint-Denis) pod Paryżem. W 1239 roku św. Ludwik IX wykupił Koronę Cierniową od cesarza łacińskiego Baldwina i sprowadził ją z Konstantynopola na paryską wyspę, dokonując tym aktem ideowego przeniesienia zarówno Jerozolimy, jak i Konstantynopola do Paryża. Odczytywano to jako symboliczne podniesienie miasta do rangi wspomnianych miejsc ${ }^{76}$. W tym kontekście jądrem nowej ideowej stolicy cesarstwa była wyspa na Sekwanie. Korona Cierniowa, będąca atrybutem Króla Królów, a należąca do francuskiego monarchy, dawała asumpt do przyrównywania go do Zbawiciela i określania jako rex imago Christi ${ }^{77}$. W latach 1241-1242 Ludwik IX umieścił w swojej kaplicy pałacowej kolejne relikwie pasyjne ${ }^{78}$. W ten sposób Paryż zyskał godność najwspanialszego relikwiarza chrześcijaństwa, w którym Île de la Cité z kaplicą Sainte-Chapelle odgrywała szczególną rolę.

Ten skrawek ziemi był wyjątkowy także z powodu związanych z nim lokalnych świętych, takich jak Dionizy - patron Francji - i Genowefa - patronka Paryża, którzy byli jednocześnie czczeni w całym królestwie i poza jego granicami. Dwie świątynie na wyspie - Saint-Denis-du-Pas i Saint-Denis-de-la-Chartre - należały do grupy ośmiu kościołów stacyjnych ważnej dla tradycyjnej paryskiej pobożności pielgrzymki ku czci pierwszego biskupa Paryża

73 Zob. J. Pysiak, Król..., dz. cyt., s. 356-359.

${ }^{74}$ Więcej na ten temat zob. J. Pysiak, Król..., dz. cyt., s. 119-250.

75 Zob. J. Pysiak, Król..., dz. cyt., s. 355-383.

${ }^{76}$ Zob. J. Pysiak, Król..., dz. cyt., s. 267-283.

77 Zob. J. Pysiak, Król..., dz. cyt., s. 356-359.

${ }_{78}$ Zob. J. Pysiak, Król..., dz. cyt., s. 293-301. 
i męczennika z III wieku ${ }^{79}$. Szczególną propagatorką jego kultu wśród Paryżan była św. Genowefa, żyjąca na wyspie w v wieku, co upamiętniały kościoły Sainte-Geneviève-la-Petite i Saint-Germain-le-Vieux.

Pozostali miejscowi święci, którym na wyspie dedykowano w sumie 11 kościołów, również byli mocno związani z galijskimi korzeniami chrześcijaństwa francuskiego. Oprócz św. Dionizego na Île de la Cité czczono jeszcze dwóch biskupów Paryża - Germana (v w.) i Landeryka (viI w.) oraz pierwszego biskupa Limoges - Marcjala (III w.), biskupa Orleanu - Aniana (IV-V w.) i biskupa Noyon - Eligiusza (vı w.). Marcjal i Anian przelali krew męczeńską za Chrystusa, podobnie jak Symforiusz (II w.) - nawrócony szlachetnie urodzony poganin, który również odbierał cześć na Cité. Należy jeszcze pamiętać o tutejszych świętych niewiastach związanych z życiem monastycznym - Marinie i Aurorze. Wezwania kościołów upamiętniające pierwszych galijskich świętych - męczenników, biskupów, mniszki - odcisnęły najmocniejsze piętno na specyfice i charakterze religijności tego obszaru i wskazywały, jak fundamentalna dla początków chrześcijaństwa była wyspa. Dobitnie poświadczały charakter tożsamości kulturowej i korzenie państwowości Francji określanej jako „pierworodna córa Kościoła”.

Wybór pozostałych patronów kościołów wybudowanych w obrębie Île de la Cité był często uwarunkowany bądź ich popularnością (Mikołaj, Agnieszka, Piotr, Bartłomiej), bądź rolą patronacką (św. Łukasz - orędownik malarzy, św. Michał - patron m.in. Francji), ewentualnie funkcją danego przybytku, np. baptysterium patronował Jan Chrzciciel, a szpitalowi - św. Krzysztof, opiekun podróżnych i obcych, których tam przygarniano. Szczególnie wymowne było wezwanie powstałego w dawnej synagodze kościoła św. Marii Magdaleny, będącej wzorem nawróconej grzesznicy i Żydówki. Taki wybór patronki dla świątyni ulokowanej w dawnej bożnicy mógł być rodzajem wyrazów uznania dla Żydów, którzy - przechodząc na chrześcijaństwo - uniknęli wygnania z Francji.

W stolicy królestwa oddawano cześć licznej rzeszy świętych, a ich kult znajdował materialny wyraz w dedykowanych im świątyniach rozsianych w mieście. Paryż, przyrównywany przez Knobelsdorfa do Rzymu, szczycił się imponującą liczbą kościołów. Ich mnogość podnosiła prestiż miasta, świadcząc nie tylko o pobożności, ale również o zamożności jego mieszkańców. Poeta ujął tę prawdę następującymi słowami:

79 Patrz przyp. 18. 
Każdy święty tu własną otrzymuje świątynię.

$\mathrm{Na}$ niezliczonych ołtarzach płoną kadzidlane ognie.

Cechą ubogiego miasta jest ograniczać się;

W bogatym inaczej, rzadkie są place bez świątyni ${ }^{80}$.

${ }^{80}$ E. Knobelsdorf, Opisanie..., dz. cyt., s. 22, wersy 341-344. 


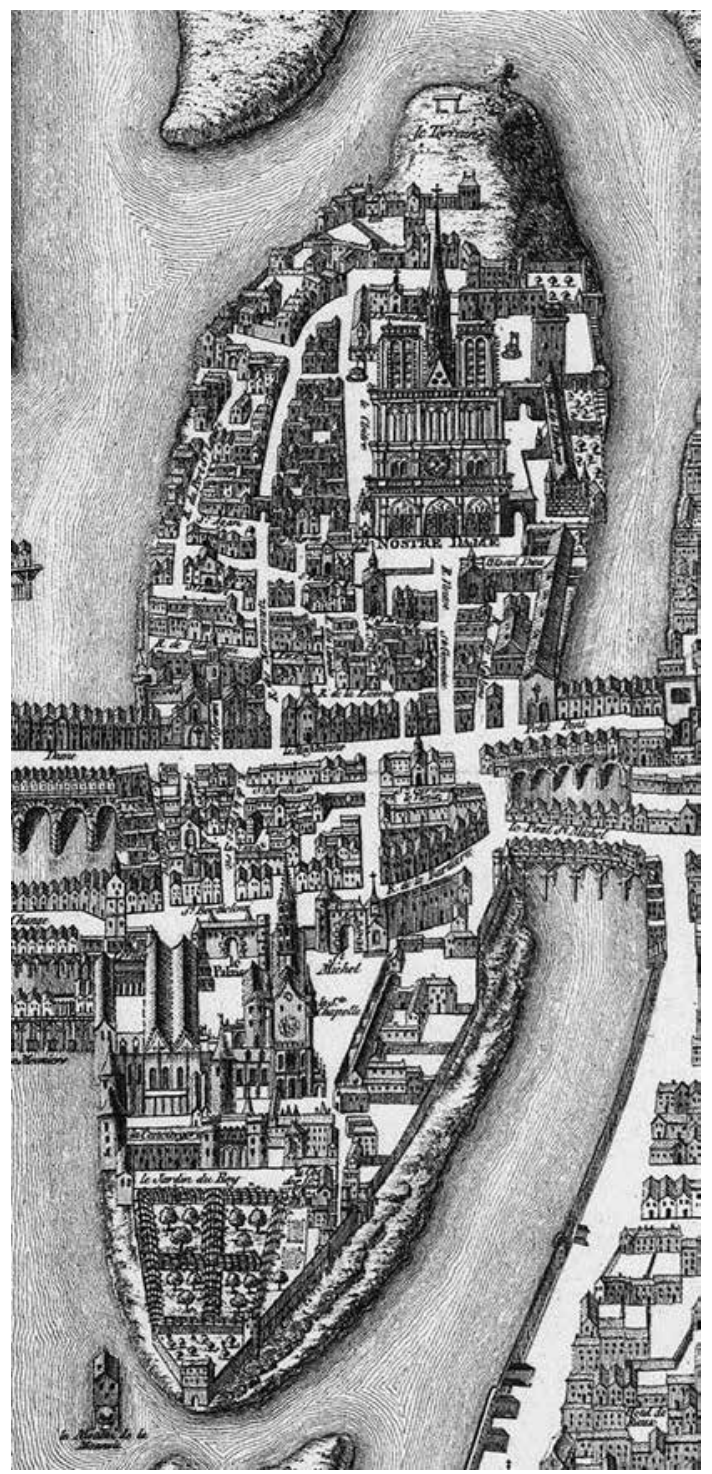

Il. 1. Plan Île de la Cité - fragment mapy Paryża z ok. 1550 roku. Ville, cité et université de Paris, zw. Plan de Saint-Victor, skopiowanej przez Guillaume’a Dheullanda w 1756 roku. Bibliothèque nationale de France, Département des Cartes et plans, nr inw. CPL GE DD-2987 (809 B) 


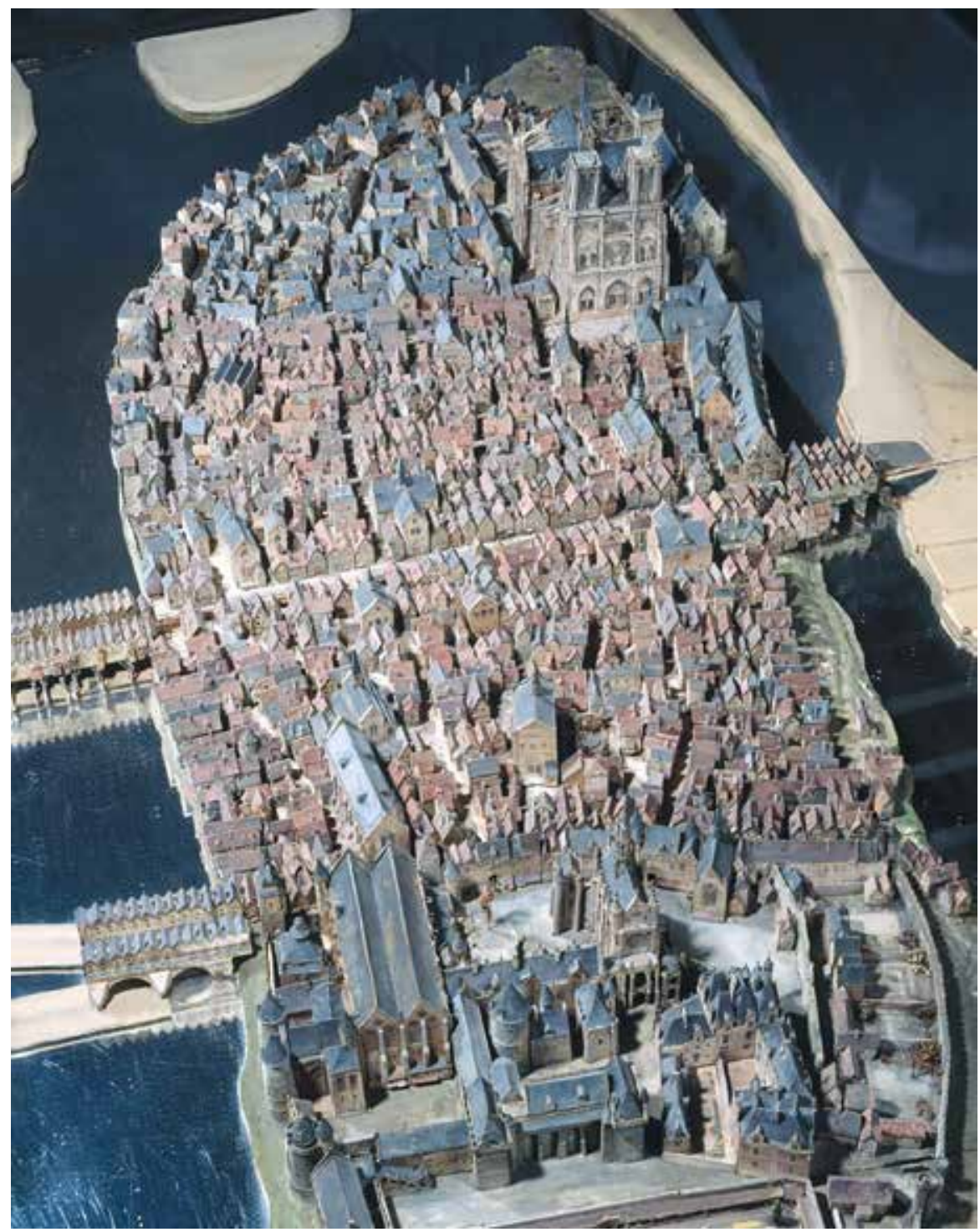

Il. 2. Makieta Île de la Cité z ok. 1527 roku wykonana przez Théodore’a Hoffbauera ok. 1900 roku. Musée Carnavalet, Histoire de Paris, nr inw. PM 8 (http://www. carnavalet.paris.fr/fr/collections/l-ile-de-la-cite-vers-1527) 


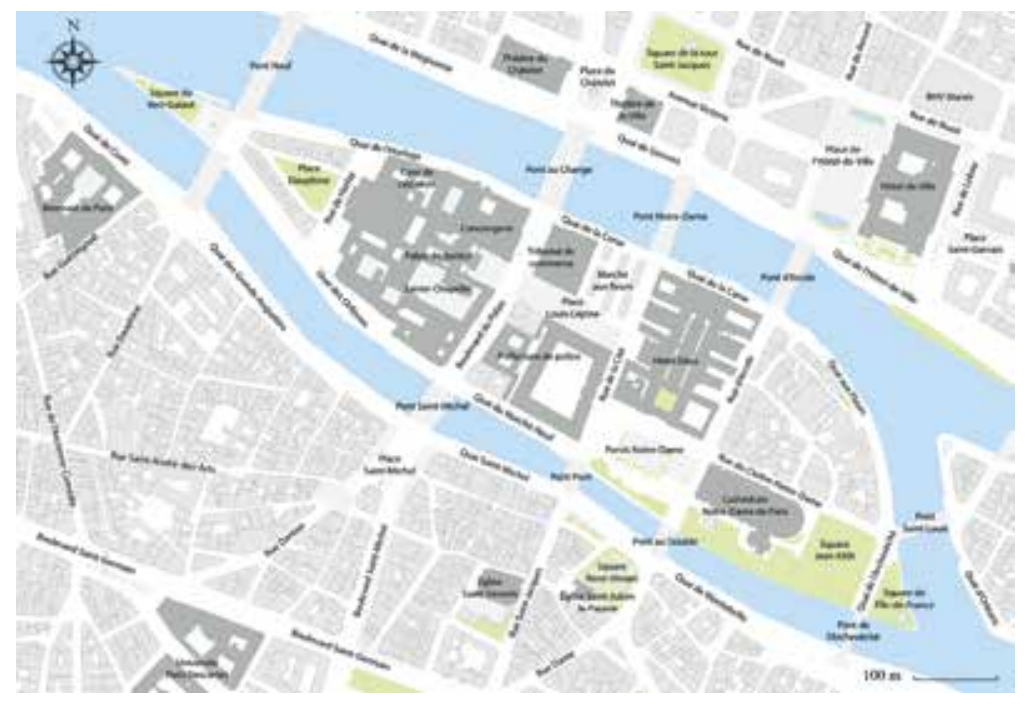

Il. 3. Współczesna mapa Île de la Cité

\section{ABSTRAKT}

Przywołanie obrazu średniowiecznej zabudowy kolebki stolicy Francji stanowi podstawę do namysłu nad charakterem jej utraconego religijnego i kulturowego dziedzictwa nie tylko w wymiarze materialnym, ale i duchowym, oraz nad wymową ideową nieistniejącej już sfery sacrum, w przeszłości zdecydowanie wyróżniającej się spośród świeckiej zabudowy wyspy. Świątynie miały nie tylko znaczenie religijne, lecz także polityczne i propagandowe. Przechowywane w nich święte relikwie, a szczególnie sprowadzona z Konstantynopola na paryską wyspę przez św. Ludwika IX w 1239 roku Korona Cierniowa, podniosły Paryż do rangi nowej ideowej stolicy cesarstwa. Wezwania kościołów upamiętniające pierwszych galijskich świętych wskazywały, jak fundamentalna dla początków chrześcijaństwa we Francji była wyspa. Bogata sfera sacrum podnosiła prestiż miasta, świadcząc zarówno o pobożności, jak i zamożności jego mieszkańców. Strefa sacrum Île de la Cité stanowiła istotę dawnej francuskiej religijności, w której była zakorzeniona cała tradycyjna kultura tego narodu.

\section{SŁOWA KLUCzowe}

Paryż, Île de la Cité, architektura sakralna, francuska religijność, francuska kultura, historia Francji 


\section{Abstract \\ The lost legacy of the 'eldest daughter of the Church' exemplified by sacral architecture of the former Île de la Cité}

Conjuring up the image of the medieval buildings in the cradle of the capital of France triggers reflection on the nature of its lost religious and cultural legacy both in the material and spiritual aspect. It also evokes thoughts on the ideological significance of its - no longer existing - sacral architecture, which stood out from other buildings on the island. The temples were important not only from the religious perspective but also from political and propaganda ones. Holy relics kept in them, especially the Crown of Thorns brought to the island from Constantinople by King Louis Ix in 1239, elevated Paris to the rank of a new ideological capital of the empire. Dedicating churches to the first Gallic saints can be viewed as evidence of the significance of the island at the dawn of Christianity. Its opulent sacral architecture raised the prestige of the city and proved both its religiosity and prosperity. Sacral architecture of Île de la Cité was the essence of old French religiosity in which the whole traditional culture of France was rooted.

\section{KeYWORDS}

Paris, Île de la Cité, sacral architecture, French religiosity, culture of France, history of France

\section{Bibliografia}

Archon L., Histoire ecclesiastique de la Chapelle des rois de France, Paris 1711.

Bourassin E., Sainte Geneviève, Monaco 1997.

Bove B., Espace, piété et parenté à Paris aux XIIIe-XIve siècles d'après les fondations d'anniversaires des familles échevinales, w: Religion et société urbaine au Moyen Age. Mélanges offerts à Jean-Louis Biget, Paris 2000, s. 253-281.

Bove B., Les palais royaux à Paris au Moyen Age (Xıe-Xve siècles), w: Palais et Pouvoir, de Constantinople à Versailles, dir. M.-F. Auzepy, J. Cornette, Saint-Denis 2003 (Temps \& Espaces).

Cartulaire général de Paris, ou Recueil de documents relatifs à l'histoire et à la topographie de Paris, formé et publié par R. de Lasteyrie, t. 1: 528-1180, Paris 1887.

Cohen M., The Sainte-Chapelle and the Construction of Sacral Monarchy. Royal Architecture in Thirteenth-Century Paris, Cambridge 2014.

Coury Ch., L'Hôtel-Dieu de Paris, treize siècles de soins, d'enseignement et de recherche, Paris 1969. 
Dectot X., Sculptures des XIe-XIIe siècles, roman et premier art gothique. Catalogue Musée national du Moyen Âge Thermes de Cluny, Paris 2005.

Dehoux E., Prétentions et revendications du roi capétien. Saint Michel, le prince et la loi (XIIe-XIIIe siècles), w: Le roi fontaine de justice. Pouvoir justicier et pouvoir royal au Moyen Âge et à la Renaissance, sous la direction de B. Meniel et B. Ribemont, Paris 2012, s. 103-127.

Delhumeau H., Le palais de la Cité, du Palais des rois de France au Palais de Justice, Paris 2011.

Deuffic J.-L., L’exode des corps saints hors de Bretagne (vire-XIIe s.): des reliques au culte liturgique, w: Reliques et sainteté dans l'espace médiéval, éd. J.-L. Deuffic, „PECia. Ressources en médiévistique" 8-11 (2005), s. 355-423, https://doi.org/10.1484/J. PECIA.5.101568 (27.09.2018).

Dictionnaire des dates, des faits, des lieux et des hommes historiques; ou, Les tables de l'histoire, répertoire alphabétique de chronologie universelle, sous la direction de A.-L. d'Harmonville, Paris 1843.

Dolbeau F., Vie et Miracles de sainte Aure, abbesse, jadis vénérée à Paris, „Bollandiana. Revue critique d'hagiographie" 125 (2007) no 1, s. 17-91.

Dumouchel B., L'église Saint-Denis-du-Pas, „Bulletin de la Société de l'histoire de Paris et de l'île-de-France" $119^{\mathrm{e}}$ à $122^{\mathrm{e}}$ années (1992-1993-1994), s. 95-115.

Dumouchel B., L'église Sainte-Marie-Madeleine ou La Madeleine-en-la-Cité (1182-1794), „Bulletin de la Société de l'histoire de Paris et de lîle-de-France” $115^{\mathrm{e}}$ année (1988, [1989]), s. 21-46.

Dumouchel B., L’église Sainte-Marine, „Bulletin de la Société de l'histoire de Paris et de l'Île-de-France" $125^{\mathrm{e}}$ à 128 e années (1998-1999-2000-2001 [2002]), s. 30-47.

Dumouchel B., L’église Saint-Germain-le-Vieux, „Bulletin de la Société de l'histoire de Paris et de l'Île-de-France" $117^{\mathrm{e}}$ année (1990 [1992]), s. 19-44.

Dumouchel B., Léglise Saint-Jean-le-Rond, „Bulletin de la Société de l'histoire de Paris et de l'Île-de-France" $118^{\mathrm{e}}$ année (1991), s. 17-34.

Dumouchel B., L'église Saint-Pierre-aux-Bœufs, „Bulletin de la Société de l'histoire de Paris et de l'Île-de-France" $122^{\mathrm{e}}$ à $124^{\mathrm{e}}$ années (1995-1997), s. 15-37.

Dumouchel B., L’église Saint-Symphorien-en-la-Cité(1206-1868), „Bulletin de la Société de l'histoire de Paris et de l'Île-de-France" $113^{\mathrm{e}}$ et $114^{\mathrm{e}}$ années (1986-1987 [1988]), s. $61-80$.

Dumouchel B., Le prieuré de Saint-Denis de La Chartre, „Paris et Île-de-France. Mémoires publiés par la Fédération des Sociétés historiques et archéologiques de Paris et de l'Île-de-France" 49 (1998), s. 7-26.

Erlande-Brandenburg A., Le grand dessein de Maurice de Sully (1160), w: Notre-Dame de Paris. Un manifeste chrétien, 1160-1230. Colloque organisé à l'Institut 
de France le vendredi 12 décembre 2003, actes édités par M. Lemoine, Turnhout 2004, s. 71-92 (Rencontres Médiévales Européennes, 4).

Escher K., Lebedynsky I., Le dossier Attila, Paris 2007.

Fabiański M., Przesławne miasto i drugi Rzym. Kraków i jego sztuka w oczach współczesnych $w$ czasach największej świetności, w: Urbs celeberrima. Księga pamiątkowa na 750 -lecie lokacji Krakowa, red. A. Grzybkowski, Z. Żygulski jun., T. Grzybkowska, Kraków 2008, s. 85-170.

Fleury M., La cathédrale mérovingienne Saint-Étienne de Paris, „Dossiers d’Archéologie" novembre $1996 \mathrm{n}^{\circ} 218$, s. 40-45.

Fleury M., La Cathédrale merovingienne Saint-Étienne de Paris, w: Landschaft und Geschichte. Festschrift für Franz Petri für seinem 65. Geburtstag, Hrsg. G. Droege, P. Schöller, R. Schützeichel, M. Zender, Bonn 1970, s. 211-221.

Fleury M., La crypte archéologique du parvis Notre-Dame à Paris, „Archéologia” octobre $1980 \mathrm{n}^{\circ} 147$, s. 6-29.

Foncin M., La Cité, „Annales de Géographie” 40 (1931) n 227, s. 479-503.

Fosseyeux M., L'Hôtel-Dieu de Paris au XviIe et XvirIe siècle, Paris 1912.

Gane R., Le Chapitre de Notre-Dame de Paris au XIve siècle. Étude sociale d'un groupe canonial, Saint-Etienne 1999.

Gaulle J. de, Nouvelle histoire de Paris et de ses environs, Paris 1839.

Grant L., Heber-Suffrin F., Johnson D., La chapelle Saint-Aignan à Paris, „Bulletin Monumental" 157 (1999) nº 3, s. 283-299.

Henriet J., A l'aube de larchitecture gothique, Besançon 2005.

Heuzey F., Curiosités de la cité de Paris. Histoire étymologique de ses rues nouvelles, anciennes ou supprimées, recherches archéologiques sur ses antiquités, monuments et maisons remarquables, Paris 1864.

Hillairet J., Lîle de la Cité, Paris 1969.

Hryszko B., Od sacrum do profanum. Desakralizacja Île de la Cité w Paryżu w XVIII i XIX wieku, w: Sacrum w mieście: wymiar kulturowy, religijny i społeczny, t. 2: Epoka nowożytna i czasy współczesne, red. D. Quirini-Popławska, Ł. Burkiewicz, Kraków 2016, s. 131-155.

Hryszko B., Rewolucja urbanistyczna na terenie Île de la Cité w Paryżu w XIX w. przyczyny i skutki, „Studia Historyczne" 61 (2018) z. 3 (243), s. 33-44.

Hubert J., Les „cathédrales doubles” de la Gaule, w: Mélanges d'histoire et d'archéologie offerts en hommage à M. Louis Blondel, Genève 1963, s. 105-125.

Hubert J., Les „cathédrales doubles” et l'histoire de la liturgie, w: Atti del primo Convegno internazionale studi longobardi, Spoleto 1952, s. 167-176.

Hubert J., Les origines de Notre-Dame de Paris, „Revue d'histoire de l'Église de France” $50(1964) n^{\circ} 147$, s. 5-26. 
Jaillot J.-B.-M., Recherches critique historiques et topographiques sur la ville de Paris, avec une notice sur la vie et l'ouvre de l'auteur, par M. Fleury, t. 1: Quartier de la Cité, Paris 1977.

Knobelsdorf E., Opisanie Paryża, tłum. J. Mrukówna, wstęp i oprac. J. Starnawski, Łódź 1994 (Literatura dla Wszystkich, 7).

Lafaurie J., Eligius monetarius, „Revue numismatique” 6e serie, 19 (1977), s. 111-151.

Lefranc O. V., Racines orientales du système monarchique des Capétiens. Les reliques de la Passion, „Revue Française d'Histoire des Idées Politiques” 2002/1 (n $\left.{ }^{\circ} 15\right)$, s. 3-15, DOI: 10.3917/rfhip.015.0003

Leniaud J.-M., Perrot F., La Sainte-Chapelle, Paris 1991.

McKnight Crosby S., The Royal Abbey of Saint-Denis: From Its Beginnings to the Death of Suger, 475-1151, ed. P. Z. Blum, New Heven-London 1987.

Merlet R., Les origines du monastère de Saint-Magloire de Paris, „Bibliothèque de l'École des chartes" 56 (1895), s. 237-273.

Morand S.-J., Histoire de la Ste-Chapelle royale du Palais, enrichie de planches, Paris 1790.

Nortier M., La chapelle Saint-Michel du Palais à Paris, siège de la confrérie de pèlerins du Mont-Saint-Michel, „Les Amis du Mont-Saint-Michel” 2000 n 105, s. 32-45.

Périn P., Paris mérovingien, 'sedes regia', „Klio - Beiträge zur Alten Geschichte” 71 (1989), s. 487-502.

Pronteau J., Étude sur le parvis Notre-Dame à Paris et les maisons des Enfants Trouvés au parvis, w: M. Fleury, J. Pronteau, Histoire de Paris, Paris 1974, s. 537-566 (École pratique des hautes études. $4^{\mathrm{e}}$ section, Sciences historiques et philologiques, 106). Pysiak J., Król i Korona Cierniowa. Kult relikwii we Francji Kapetyngów, Warszawa 2012. Renaudin E., Paris-exposition ou guide à Paris en 1867. Histoire, monuments, musées, théâtres, curiosités vie pratique, Paris 1867.

http://data.bnf.fr/13508340/paroisse_saint-barthelemy_paris/(27.09.2018). 